swer to that question demands that we are able to grasp where this new power sits in the landscape of powers and how it works. The book is a significant step towards developing such a counter-power.

Jude McCulloch

Monash University

\title{
Dan Malleck, When Good Drugs go Bad: Opium, Medicine, and the Origins of Canada's Drug Laws (Toronto: UBC Press, 2015). 320pp. Paperback $\$ 34.95$.
}

On 30 May 1908, William Lyon Mackenzie King, then Deputy Minister of Labour, replied to a letter from Peter Hing, a leader of the Chinese Anti-Opium League of Vancouver, who had asked Mackenzie King if he could inquire into the manufacture of opium in Vancouver while also investigating the 1907 anti-Asiatic riots. Mackenzie King responded that there could be "but one opinion ... toward this evil, which ... does so much to destroy not only the lives of individuals, but the manhood of a nation."1 Mackenzie King's statement displays many of the themes explored in Dan Malleck's When Good Drugs Go Bad: Opium, Medicine, and the Origins of Canada's Drug Laws: race, gender, and the relationship between individual health and national welfare. However, while many historians have located the origins of Canada's drug laws in anti-Asian racism, Malleck argues that these historians have overemphasized the importance of anti-Chinese sentiment. Rather, both the Opium Act and the Patent or Proprietary Medicine Act of 1908 were the outcome a longer series of social and cultural developments_-particularly the professionalization of physicians and pharmacists — and the ways that these groups imagined themselves as protectors of national health and integrity. Regulation of medicinal and non-medicinal drug use drew upon a common set of late-nineteenth century anxieties about national health that paved the way for drug prohibition — a development all the more remarkable given the weight of laissez-faire arguments about the medical marketplace.

Prior to the early-twentieth century, Canadians could access opium and other drugs primarily through pharmacies. However, as Malleck demonstrates with pharmacy records and home-remedy books, opium competed in a relatively open medical marketplace characterized by multiple alternative therapies. "The main user of opiates was the medical profession itself," Malleck reminds us, and by the midnineteenth century, opium had become a crucial tool for an emerging medical profession that claimed therapeutic superiority over alternatives such as homeopathy $(27-28)$.

While opium was a powerful medicine, it was also a dangerous one. Cases of opium poisoning and addiction brought about by medical use raised the stakes for Canada's doctors as they negotiated their emerging professional identity, often 
in full view of the public, as in the mid-century poisoning cases of Job Broom and John Blackie. Indeed, William Osler captured much of the anxiety about the medical role of opium in his 1891 Principles and Practices of Medicine, when he related his frustration that many doctors carelessly administered opiates for "simple headache or mild neuralgia" (49).

Concern about "acute and chronic poisoning" with opiates led to the creation of Canada's first drug laws, a patchwork of provincial pharmacy legislation beginning with the 1871 Pharmacy Act of Ontario. Building on earlier strychnine legislation, these were some of the first laws to restrict the sale of specific substances to a professional group — a development that was anathema to the anti-monopoly sentiments of the period. While pharmacists and doctors disagreed about which group was best able to resist the temptations of the market while protecting the public (they notably tangled over the so-called "percentage system"), they largely agreed on the necessity of regulations that placed control of narcotics in professional hands.

It is here that Malleck's story connects to that of Chinese opium smoking, although in a less direct way than in other histories of drug prohibition. What linked iatrogenic opium abuse with Chinese opium smoking in British Columbia was a shared concern among elite Canadians for national health and morality, often connected in the writings of medical reformers such as Henry Howard and Stephen Lett, Canada's first addiction specialist. The emerging medical conception of addiction relied on the fashionable scientific notion of "diathesis," a heredity or acquired predisposition to physical disorder that made Canada's social elite particularly vulnerable to physical and moral corruption. Simultaneously, the threat of Chinese opium smoking, although initially less worrying than Chinese labour, was that it would corrupt the social elite by luring and debauching the young. It was against this background that Canada's physicians and pharmacists asserted their authority to protect the nation's future.

This assertion of authority came initially in the form of lobbying for restrictions on patent and proprietary medicines. Again, while physicians and pharmacists argued over whose profession was sufficiently selfless to protect the nation's health, both groups agreed that the common presence of addictive drugs such as opium and cocaine in patent medicines made them a threat. Beginning in 1885 with changes to Quebec's Pharmacy Act, pharmacists and doctors lobbied for stricter controls, often in the face of free market ideology. This pushback blunted a number of provincial attempts to regulate patent medicines, leading to a push for national legislation. The campaign for national patent medicine legislation catalyzed the formation of the Canadian Pharmaceutical Association, and led one pharmacist to state that "the health of the public is at stake, and an insidious foe more deadly than alcoholism even is sapping character, energy and life, out of the nation" (2089).

Malleck's final chapter details the passage of the Opium Act of 1908, and 
its merger with the Patent or Proprietary Medicine Act to become the Opium and Drugs Act of 1911. When Mackenzie King stated that opium's "baneful influences are too well known," he was drawing on nearly half-a-century of professional dialogue that transformed opium from a valuable medicine into an existential threat to the nation. Malleck's richly researched narrative may not have completely toppled arguments about the "racist roots" of Canada's drug laws; indeed, I was left wondering whether Malleck may have overstated his case somewhat, given the later clearly racialized enforcement of these new laws. Nevertheless, When Good Drugs Go Bad deepens our understanding of the connections that could be so easily drawn between the body, race, medicine and the nation in early twentieth century Canada.

Yvan Prkachin

Harvard University

\section{NOTES}

${ }^{1}$ W.L. Mackenzie King, "Report by W.L. Mackenzie King, C.M.G., on the Need for the Suppression of the Opium Traffic in Canada (Ottawa: Sessional Paper 36b, 1908)", 6.

Gada Mahrouse, Conflicted Commitments: Race, Privilege, and Power in Transnational Solidarity Activism (Kingston: McGill-Queen's University Press, 2014). 248pp. Paperback \$27.95.

This work addresses an important issue and practice in the contemporary context of global capitalist development. In particular it focuses on recent manifestations of transnational activism and solidarity of a certain type. This involves non-violent, largely witnessing, approaches in which activists from the global North journey to sites of conflict in the global South as a means of observing and supposedly shielding or protecting local communities, while sharing stories of injustice in their home locales.

That is the imagined intention anyway. As Gada Mahrouse effectively argues and illustrates in Conflicted Commitments, actual outcomes are often at odds with intentions and practices more complex and troubled than imagined or hoped for.

Mahrouse gives dedicated and developed attention and analysis to situations of struggle in Palestine and Iraq in the post-9/11 "eternal war on terror" context. The focus here-and this becomes a problem — is exclusively on non-violent, pacifist groups that operate largely within a human rights framework. These groups can generally (though not uniformly) be located within the terrain of global NGOs. The author examines racialized privilege (white, middle class activists) deployed, embodied, to raise awareness of acts of solidarity. The deployment of white, Western privilege actually re/produces structures and practices of colonialism and imperialism. 